\title{
Är den tyska litteraturen död i Sverige?
}

\section{Av Bärbel Westphal, universitetsadjunkt i tyska}

\author{
Länk till presentation av Bärbel Westphal
}

Vad skulle du säga om du ombads nämna två eller tre nu levande tyskspråkiga, framgångsrika författare? Böll, Frisch och Dürrenmatt dog för några år sedan. Grass, Lenz och Walser lever - men skriver de? Och visst borde det finnas unga intressanta författare?

I somras gick jag på antikvariat i Göteborg och gjorde mig inga större förhoppningar om att hitta tyskspråkig litteratur. Men se, jag fyndade! Ett tiotal högklassiga verk av unga tyska författare reades till ett pris som var en tredjedel av det redan låga pris man skulle ha betalat i Tyskland. Jag hittade bl.a. riktiga storsäljare som Jens Sparschuhs "Der Zimmersprungbrunnen" (1995) och Kerstin Hensels "Tanz am Kanal" (1994), till råga på allt inbundna.

Jag kan bara spekulera i varför dessa böcker står på antikvariat. Den tänkta läsargruppen: studenter som läser tyska, lärare eller andra som behärskar språket har inte precis kastat sig över dem när de stod i bokhandelns hylla. Det må så vara när det gäller litteratur på originalspråk, men det ser inte mycket bättre ut för de böcker som har översatts till svenska.

En anledning är att svensk bokhandel har ovanan att gallra ut böcker efter bara ett par år för att skicka dem till papperskvarnen. Det är inte bra för inhemsk litteratur och ännu mera ödesdigert för den utländska som behöver lite längre tid på sig att bli uppmärksammad av den vanlige bokköparen. Ett annat skäl är att tyskspråkig litteratur överhuvudtaget inte prioriteras av svenska förlag.

I Akademibokhandelns pocketguide för 1998 finns 21 översatta titlar av tyskspråkiga författare bland totalt 1700 . Det är 1,2 \%. Om det inte vore för enskilda eldsjälar i förlagsbranschen skulle vi nog aldrig ens ha hört namn som Christa Wolf, Peter Handke eller Thomas Bernhard. Som Per Landin redan 1990 visade i sin avhandling "Von dort nach hier" om receptionen av tysk litteratur i Sverige, betraktas en tysk bok alltid som en förlustaffär. Men man gör inte heller särskilt mycket PR för att ändra på den saken.

För den som går en runda i stadens bokaffärer blir saken uppenbar. Bokhandeln är inte som tidigare den självklara kulturinstitution som värnar om mångfalden i utbudet. Hit kan inte en vanlig bokköpare längre gå för att se vad som finns i utländsk litteratur - den anglosaxiska underhållningsgenren undantagen. Med tanke på det snäva utbudet måste förlagen och bokhandeln i vinstsyftets namn ha dumförklarat sina kunder. Bokklubbarna som ju tagit över en större del av bokförsäljningen och pressat priserna har heller inget bättre utbud att erbjuda. Den som inte redan arbetar med litteratur på ett eller annat sätt kommer förmodligen aldrig att få upp ögonen för vad som skrivs i våra grannländer.

Vill man t.ex. få tag i en bok av 1972 års nobelpristagare Heinrich Böll får man bege sig till biblioteken eller antikvariaten som alltmer framstår som rena guldgruvan när det gäller förstklassig utländsk litteratur. En biblioteksundersökning från 1985 delade in böcker i tre grupper: klassiker, kvalitetslitteratur och underhållningslitteratur. Undersökningen visade att av andelen tysk litteratur som lånas ut är 61,4\% s.k. kvalitetslitteratur, jämfört med engelskans 19,3\% och 31,5\% för franskan. För den svenska litteraturens del är motsvarande siffra 43\%. Det är självklart att svenskar lånar andelsmässigt flest svenska böcker, ändå borde ovanstående siffror få förlagen att tänka om vad gäller svenska läsares 
intressen. Frågan är om en liknande undersökning idag skulle få totalt avvikande resultat.

För mig framstår det som obegripligt varför inte ens tyska klassiker som Thomas Manns "Buddenbrooks", Günter Grass "Blecktrumman", Max Frischs "Homo Faber" eller Wallraffs ständigt aktuella reportageböcker ges ut i pocketformat. De är inte "svårlästa" och "snåriga", eller skrivna med en för en svensk obegriplig tysk politisk bakgrund. Förlagen borde kunna anamma skivbolaget Naxos filosofi. Vill man verka för kulturen måste den vara lättillgänglig och prisvärd. Det är klart att ingen vill "testköpa" nyare tyskspråkig litteratur för tre till fyrahundra kronor när man ens aldrig har hört talas om Urs Widmer, Durs Grünbein, Elfriede Jelinek, Christoph Ransmayr, eller Peter Schneider. I årets pocketutgåvor finns dock Erica Fischer, Gaby Hauptmann, Ingrid Noll och naturligtvis Patrick Süskinds bestseller "Parfymen", den senare det riktigt stora undantaget vad gäller modern tysk litteratur.

All försäljning vilar naturligtvis på ett gediget arbete vad gäller marknadsföring och reklam. Ta det tyska förlaget Hanser som föredömligt lanserade svenska författare på bred front med sin slogan: "Svenskarna kommer!" Så fick Lars Gustafsson, P-O Enqvist och Thomas Tranströmer sina tyska läsare och i deras kölvatten - får man förmoda - Kerstin Ekman, Jan Guillou och Marianne Fredriksson också enorma framgångar.

Enligt min mening är tiden inne för ett trendbrott. Efter krigsslutet 1945 tog utlandet, så också Sverige, av förklarliga skäl avstånd från en månghundraårig andlig och intellektuell gemenskap med de tyskspråkiga länderna för att vända sig till det anglosaxiska området. Så bröts kontakten med Europa och därmed faktiskt också med vårt eget kulturarv, vilket ju t.ex. återspeglas i konsertföreningarnas programblad. När spelas det inte Bach, Mozart eller Beethoven? Men: det vi anser som vår gemensamma europeiska kultur ligger före eller omkring förra sekelskiftet! Nu är det emellertid snart tio år sedan muren föll, Sverige har gått med i EU och står redan mitt i en gemensam europeisk marknad. Det borde därför också vara dags att återknyta våra kulturella band.

Efter att ha bearbetat andra världskriget och dess följder har den tyska litteraturen nu på ett befriande sätt tagit sig an murens fall, man låter också i högre grad fantasin och humorn spira. De schweiziska och österrikiska författarna står just nu rent av för en kavalkad av högklassig och roande litteratur. Läs alltså gärna: Urs Widmer: "I Kongo", Robert Schneider "Sömnens broder", Christoph Ransmayr "Den sista världen" eller varför inte de två ovannämnda av Sparschuh och Hensel. Fråga gärna på bokhandeln. Kanske har du tur, fast jag skulle tippa att du får gå till biblioteket.

Svenskt förlagsväsen har en uppgift att fylla. Man kan alltid peka på att den svenska marknaden är för liten för "smal" litteratur - vad är åtta mot Tysklands åttio miljoner invånare. Men man skulle också kunna hävda att de åttio miljonerna i Tyskland inte torde ha det ringaste intresse av ett litet lands litteratur som den svenska. Intresse kan dock väckas och intresset för tysk kultur och historia i Sverige är på inget vis utdött.

Bokfloden i världen är enorm och för den genomsnittlige bokälskaren är det inte lätt att vare sig få en överblick över denna eller att följa de senaste trenderna. Det är dock helt omöjligt om medier och bokbranschens aktörer enbart följer marknadsmässiga principer och helt har tappat intresset för att verka för folkbildning, upplysning och mångfald.

\section{(C) Bärbel Westphal}

